\title{
FIRST YEAR HOSPITALISATION COSTS FOR THE SPINAL CORD INJURED PATIENT
}

\author{
By Samuel B. Webb, JR, Dr P.H., ${ }^{1}$ Evarists Berzins, M.P.H., ${ }^{2}$
}

Thomas S. WingaRdNER, M.P.H., ${ }^{3}$ and M. ElisabeTH LORENZI, B.A. ${ }^{4}$

1 Department of Epidemiology and Public Health, National Spinal Injuries Centre, Stoke-Mandeville Hospital, Aylesbury, Bucks, England; ${ }^{2}$ Department of Epidemiology and Public Health, Yale University School of Medicine; ${ }^{3}$ Yale-New Haven Hospital, New Haven, Connecticut, U.S.A.; ${ }^{4}$ Department of Epidemiology and Public Health, Yale University School of Medicine

Abstract. This retrospective, descriptive study presents the actual first year hospitalisation costs for a series of 85 spinal cord injured patients, covered by Workmen's Compensation Insurance and cared for in a variety of United States institutions. Mean first year hospital costs for all patients was $\$ 35,676$. For quadriplegics, $\$ 42,240$; and paraplegics, $\$ 32,6$ I9. During initial hospitalisation only, the average length of stay was I 84 days and mean cost was $\$ 28,637$. Room and board comprised 52 per cent of costs; special services, 36 per cent and professional services, I I per cent. Major special service costs were private duty nursing, medications, medical supplies, respiratory and physical therapy. Major professional charges were centred in the surgical and physical medicine specialties. Home care costs averaged $\$ 4000$ per patient or $\$ 37.00$ per day.

When compared with the other studies, the costs presented here are higher though the differential is reduced markedly when median rather than mean costs are presented. When compared with the one other known study based on actual and not estimated costs, the results are markedly similar. Differences in costs between this and other studies and the reasons for same are discussed.

Key word: Cost of hospitalisation.

\section{Introduction}

Trauma to the spinal cord can be one of the most catastrophic injuries known to man, resulting in varying levels of debilitation, loss of independence and/or death. Estimates of the incidence of spinal cord injuries in the United States per year range from 25 to 54 per $1,000,000$ population. While there is an abundance of literature concerning the aetiology and treatment of spinal cord injury, to date little has been published which provides much more than reliable estimates on the cost of spinal cord injury (Charles et al., 1974). Moreover, while several authors have conjectured on the costs of this injury, with the exception of Barrie (1973) and several others (Thomas, 1974; Smart \& Sanders, 1976), little information is provided regarding methodologies utilised to obtain said estimates. Also important is that cost estimates and other findings from spinal cord injury research have proven most difficult to compare or evaluate. Most studies have very small patient populations and have looked at costs during varying time periods, treatment periods and even at dissimilar cost categories. In addition, some investigators have used costs as dependent variables in order to evaluate modes of treatment. Thankfully, several studies, some prospective, are presently under way to remedy this situation. While the most recent publication by Smart and Sanders (1976) is a good first step, unfortunately, it too relies primarily on estimated cost values.

Full postal address: Department of Epidemiology and Public Health, Yale University School of Medicine, 60 College Street, New Haven, Connecticut 065 Io, U.S.A. 


\section{Purpose, Definitions and Methodology}

The purpose of this study, hereafter referred to as the Yale Study, is to isolate and determine the direct costs to survivors of traumatic spinal cord injury for the first post-accident year. Direct cost is defined as institutional and professional charges for services rendered in the treatment of the injury. We have divided patient care episodes into initial hospitalisation (that period of hospitalisation from day of injury to first definitive discharge to home); re-entry hospitalisation (hospitalisations subsequent to the initial period); and home care (a time when no hospitalisation occurs and/or when medical care is provided at home). This typology allows us to compare certain of our results with other findings in the literature. Spinal cord injury is defined as an injury resulting in paralysis or debilitating weakness as a consequence of damage to the spinal cord.

A retrospective, descriptive design was chosen to accomplish the study objective. Workmen's Compensation files at Aetna Life and Casualty Insurance Company and the Travelers Insurance Company were reviewed and the records of patients with identifiable traumatic spinal cord injury were requested from field offices throughout the United States. Once received, the records were reviewed and, if complete, abstracted, coded and analysed. Of a total of I7I records (1950-74), 85 proved adequate for analysis. The remaining records were not used because of incompleteness of data (74), malpractice cases (2), court settlements (2), first year anniversary of injury not reached (4), died before end of first year (2), no spinal cord injury (2). The Consumer Price Index (CPI $)^{1}$ was used as an adjuster for charges in order to control for the inflationary trend of health care costs. All costs reported in this paper are in 1974 dollars.

When possible, cost values include mean and median values, as well as standard deviations in the hope that these will aid the reader in explaining the distribution and variances of costs. It must be remembered that mean values are affected more significantly than the median by extreme values. Accordingly, in spinal cord injury costs where extreme values are often the norm, the median may perhaps be the more meaningful figure. Finally, correlation analysis showed that between first year costs and length of stay there was a coefficient of +0.679 (significant at $\mathrm{P} \leqq 0.00 \mathrm{I}$ ) and between total length of stay and total hospitalisation cost (total of first year costs less home care costs) the coefficient was $+0 \cdot 74 \mathrm{I}$ (significant $\mathrm{P} \leqq 0 \cdot 00 \mathrm{I}$ ). Thus while we can assume that there is little significant difference between total costs and length of stay, there is not a I : I relationship such as is assumed in the recent study by Smart and Sanders (1976).

\section{Results}

Table I illustrates that the cost findings in the present study (Yale) are higher than is the majority of those found previously. However, use of the median total value - \$23,773-reduces the variance quite substantially. As mentioned earlier, extreme values (in the case of Yale Study initial hospital costs ranged from a low of $\$ 5$ II 3 to a high of $\$ 89,544$ ) affect the mean greatly. There would appear to be several possible explanations for the observed differences in Table I as compared to the Yale Study. The other studies analysed costs within special spinal cord injury centres where, perhaps, the more concentrated use of specialised resources

1 The authors will be happy to provide those interested with the detailed methodology of using the Consumer Price Index. However, we must charge a small fee to offset printing and postage costs. 


\section{TABLE I}

Comparative average length of stays and mean costs per SCI patient during initial hospitalisation

\begin{tabular}{|c|c|c|c|c|}
\hline & $\underset{\text { size }}{\text { Sample }}$ & $\begin{array}{c}\text { Average length } \\
\text { of stay (days) } \\
\text { initial } \\
\text { hospitalisation }\end{array}$ & $\begin{array}{l}\text { Mean cost } \\
\text { per day }\end{array}$ & $\begin{array}{l}\text { Mean initial } \\
\text { hospital costs (\$) }\end{array}$ \\
\hline $\begin{array}{l}\text { Yale Study, USA (1950-74) } \\
\text { Veterans Administration Hospital }\end{array}$ & 85 & I 84 & I69 & $28,637^{1}$ \\
\hline West Roxbury, Massachusetts (1973-75) & 37 & 220 & N.A. & N.A. \\
\hline $\begin{array}{l}\text { Southwest Regional System for Treatment } \\
\text { of SCI, Phoenix, Arizona (I970-73) } \\
\text { Midwest Regional SCI Center, Chicago, }\end{array}$ & 38 & 108 & 173 & I8,684 \\
\hline $\begin{array}{l}\text { Midwest Regional SCI Center, Chicago, } \\
\text { Illinois (I973) } \\
\text { Texas Institute of Rehabilitation and }\end{array}$ & 26 & I3 I & I60 & 20,960 \\
\hline $\begin{array}{l}\text { Research, Houston, Texas (I974) } \\
\text { Rancho Los Amigos Hospital, Downey, }\end{array}$ & 82 & I 80 & 165 & 29,700 \\
\hline California $(1967-69)^{6}$ & 197 & I70 & I4I & 23,970 \\
\hline $\begin{array}{l}\text { Lorenzi Study, Connecticut (1969-73) } \\
\text { Spain Rehabilitation Center, Birmingham, }\end{array}$ & 63 & 54 & 175 & 9,472 \\
\hline $\begin{array}{l}\text { Alabama-System (1973-74) } \\
\text { Spain Rehabilitation Center, Birmingham, }\end{array}$ & 22 & 87 & 127 & I I,035 \\
\hline Alabama-Non-system $(1973-74)^{8}$ & I3 & I66 & I09 & I8, I6I \\
\hline Smart and Sanders Study, USA (I974) ${ }^{9}$ & 3,377 & 160 & I 57 & 25,433 \\
\hline
\end{tabular}

1 This represents actual mean initial cost. The other figures represent reproduct of mean cost per day times average length of stay. It should also be noted that the median total value for the Yale study was $\$ 23,773$.

2-6 Smart, C. N. and Sanders, C. R.: The Costs of Motor Vehicle Related Spinal Cord Injuries, Insurance Institute for Highway Safety, Washington, D.C., I976, pp. 52-54.

${ }^{7}$ Lorenzi, M. E.: Economics of Catastrophic Illness: Investigation of the Cost of Spinal Cord Injury, unpublished study, I975. It should be noted that all figures from this study represent acute care hospitalisation only, thus accounting for the low length of stay and initial hospital cost figures and the high mean cost per day.

${ }^{8}$ Charles, E. D. et al.: 'Spinal Cord Injury-A Cost Benefit Analysis of Alternative Treatment Modals', Paraplegia, 12, pp. 228-23 I, I974.

${ }^{9}$ Smart and Sanders, op. cit. All figures represent simple means calculated by the authors from data presented on p. 54 .

and personnel tend to lessen length of stay and hence mean costs. Moreover, with the exception of the MWRSCIC study, it is not known whether costs such as professional fees, transportation, equipment, etc. are included. In addition, the cost inflator used in the Yale Study might be faulty though it appeared to provide as accurate an adjustment as possible. Furthermore, the time periods may not, in fact, be comparable because the Yale Study deals with a patient population injured over a period of nearly 25 years whereas the other studies deal with much shorter time periods ( $1-5$ years). The treatment of spinal injury may have changed so significantly over this time as to limit our methodology greatly. However, analysis shows no significant difference between Yale sample patients' first year cost of injury or lengths of stay between 1950-74. Thus while treatment may have changed, this is not reflected in first year costs to the patient.

Table II presents costs for initial hospitalisation and resulting hospitalisation broken down into component parts. One must note the high variance, as evidenced in the standard deviation, and the relatively small part (I I per cent) that professional fees comprise of the total bill. When special service charges are broken down further, the most significant cost was for special private duty nursing (mean 
TABLE II

Costs for spinal cord injured patients by type of charge: 1974

\begin{tabular}{|c|c|c|c|c|c|}
\hline \multirow[t]{2}{*}{ Charge } & \multicolumn{5}{|c|}{ Initial hospitalisation } \\
\hline & Mean & $\%$ & Median & $\%$ & $\begin{array}{l}\text { Standard } \\
\text { deviation }\end{array}$ \\
\hline Room and board & 14,956 & 51.5 & I I, 975 & 50.4 & 10,982 \\
\hline Special service & 10,350 & $35 \cdot 7$ & 7,210 & 30.3 & 8,939 \\
\hline Professional & 3,217 & II.O & 2,739 & II. 5 & 2,116 \\
\hline Total & 29,025 & & 23,773 & & I8,809 \\
\hline \multirow[t]{2}{*}{ Charge } & \multicolumn{5}{|c|}{ Re-entry hospitalisation } \\
\hline & Mean & $\%$ & Median & $\%$ & $\begin{array}{l}\text { Standard } \\
\text { deviation }\end{array}$ \\
\hline Room and board & $3,45 \mathrm{I}$ & 51.9 & I,796 & 55.I & 4,476 \\
\hline Special service & 2,264 & 34.0 & 969 & 29.8 & 3,183 \\
\hline Professional & 805 & I 2.1 & 380 & II.7 & $\mathrm{I}, 007$ \\
\hline Total & $6,65 \mathrm{I}$ & & 3,259 & & 7,131 \\
\hline
\end{tabular}

Source: Yale Study.

\section{TABLE III}

Home care costs for spinal cord injured patients: 1974 dollars

\begin{tabular}{|c|c|c|c|c|c|c|}
\hline Charge & Number & Mean & Median & $\begin{array}{l}\text { Standard } \\
\text { deviation }\end{array}$ & Low & High \\
\hline Outpatient/ER & 32 & 905 & 88 & 3482.7 & 6 & 20,043 \\
\hline Operating room/OPD & I & 142 & I42 & 0.0 & - & - \\
\hline X-ray & 20 & 75 & 44 & 107.8 & 7 & 520 \\
\hline Laboratory & I I & 66 & 25 & I I 4.5 & 7 & 422 \\
\hline Medications & 58 & 320 & 230 & $257 \cdot 3$ & 6 & I,318 \\
\hline Medical supplies & 54 & I,OO० & 522 & 1210.9 & 6 & 5,498 \\
\hline Physical therapy & 21 & 319 & 169 & $347 \cdot 4$ & 8 & $\mathrm{I}, 469$ \\
\hline Occupational therapy & I & 82 & 82 & 0.0 & - & - \\
\hline Nursing & 24 & $I, 542$ & 775 & 1652.1 & 34 & 4,987 \\
\hline House alterations & 18 & 4,658 & 975 & 6169.4 & 18 & 18,848 \\
\hline Auto alteration & 8 & 959 & 422 & I3I 2.7 & 139 & 4,322 \\
\hline Transportation & 33 & 361 & I97 & 419.0 & 28 & 2,030 \\
\hline Miscellaneous & 14 & 548 & 160 & 1010.0 & I I & 4,037 \\
\hline Physician fees & 46 & 726 & 66 & 2840.6 & 7 & 15,053 \\
\hline Total & 70 & 4,000 & $\mathrm{I}, 70 \mathrm{I}$ & 6248.0 & 85 & 30,334 \\
\hline
\end{tabular}


$\$ 7853$; median $\$ 2359$; standard deviation $\$ 9649$; range, $\$ 180.00$ to $\$ 36,008$ ). Other significant charge items were, not surprisingly, physical and respiratory therapy, medical supplies and pharmaceuticals. In re-entry care, it is of interest that special services and professional fees constitute basically the same percentage of total costs as in initial hospitalisation.

Table III shows home care costs for the patient population. Very striking is the diversity amongst and within charge categories. Medical supplies and home attention are significant cost factors for patients during this period. However, the high mean values for those costs is due to the high extreme values. When physicians' fees are examined closely, the trend towards high utilisation of urologists is marked, which, not surprisingly, suggests complications of urinary tract infections.

Table IV presents comparative information on home modification costs. As highlighted by Smart and Sanders, costs for quadriplegics will be higher than the mean resulting from the minimum quadriplegic's need for a wheelchair shower in the bathroom and for greater wheelchair manoeuvrability around the home. The latter calls for extra door widening, longer, less inclined ramps and a larger bedroom (Smart \& Sanders, 1976). Most interesting is the similarity between the Yale and Barrie figures. In each case these figures represent actual costs while the others presented are estimated costs.

Tables V and VI illustrate the comparative mean total first year hospital costs between our study and the latest published material. The big difference between the figures is seen in the paraplegic patient category. It must be remembered that the Smart and Sanders data are in large measure estimates, but more importantly relate to costs for specialised spinal cord injury centres. In contrast, the Yale data represent, mostly, costs from general hospitals throughout the United States. Does the higher rehospitalisation cost associated with the centres (Table VI) represent premature discharge, better follow-up, or a preventive measure (annual check-up)? Could it merely be the cost of transporting family members and nurses to care for the patients? An answer to these questions would be welcome. The reasons for the large difference in mean first year hospital costs for the paraplegic patients category are no doubt numerous. The shorter average length of stay, lower mean cost per day and lower mean initial hospital costs account for some of the differential (see Tables I, V and VI). In addition, we would hypothesise that the intensive and rigorous therapy provided patients in

\section{TABLE IV}

Comparative costs for home modifications for the spinal cord injured patient: 1974 dollars

\begin{tabular}{lc}
\hline \multicolumn{1}{c}{ Source } & $\begin{array}{c}\text { Mean home } \\
\text { modification cost (\$) }\end{array}$ \\
\hline Yale & 4,658 \\
Barrie, D. ${ }^{1}$ & 4,625 \\
Young, J. $^{2}$ & 3,000 \\
Mass. Rehab. $^{3}$ & 4,500 \\
Smart and Sanders & 4,030 \\
\hline
\end{tabular}

1-4 See Smart, C. N. and Sanders, C. R.: The Costs of Motor Vehicle Related Spinal Cord Injuries, Insurance Institute for Highway Safety, Washington, D.C., I976, pp. 55-56. 


\section{TABLE V}

Comparative average length of stay and mean first year hospital costs per SCI patient

\begin{tabular}{|c|c|c|c|c|c|c|}
\hline \multirow[t]{2}{*}{ Source } & \multicolumn{3}{|c|}{ Average length of stay } & \multicolumn{3}{|c|}{ Mean first year hospital costs } \\
\hline & Quads & Para & All & Quads & Para & All \\
\hline $\begin{array}{l}\text { Yale } \\
\text { Smart and }\end{array}$ & 248 & I89 & 206 & 42,240 & 32,619 & 35,676 \\
\hline Sanders ${ }^{1}$ & 193 & I 45 & I69 & 36,400 & 18,625 & 27,512 \\
\hline
\end{tabular}

${ }^{1}$ See Table 19, p. 74 in Smart, C. N. and Sanders, C. R.: The Costs of Motor Vehicle Related Spinal Cord Injuries, Insurance Institute for Highway Safety, Washington, D.C., I976. Above costs represent simple means of paraplegic and quadriplegic categories of the direct cost components of emergency assistance, initial hospitalisation and rehospitalisation.

TABLE VI

Comparative costs per patient per year by type of cost

\begin{tabular}{lcccc}
\hline & $\begin{array}{c}\text { Emergency } \\
\text { assistance }\end{array}$ & $\begin{array}{c}\text { Initial } \\
\text { hospitalisation }\end{array}$ & Re-hospitalisation & Total \\
\hline Yale & 388 & 28,637 & $6,65 \mathrm{I}$ & 35,676 \\
Smart and Sanders $^{1}$ & 392 & $\mathbf{1 3 , 0 9 1}$ & 8,569 & $\mathbf{2 2 , 0 5 2}$ \\
\hline
\end{tabular}

${ }^{1}$ See Table 20, p. 77 in Smart, C. N. and Sanders, C. R.: The Costs of Motor Vehicle Related Spinal Cord Injuries, Insurance Institute for Highway Safety, Washington, D.C., 1976. Costs represent simple means of category 'All SCI'.

specialised spinal units no doubt reduces costs, though this has yet to be proven conclusively. Finally, special aid centres may have long waiting lists and thus admit primarily those patients with the most promising rehabilitation potential while others remain in community hospitals or nursing homes. In addition, the philosophy of spinal cord injury treatment differs among institutions. Those places willing to discharge patients with indwelling catheters are going to have shorter lengths of stays than institutions seeking a bladder free of catheters. Finally, institutions like the VA can't pick and choose patients based on rehabilitation potential, but by law must take almost all veterans.

\section{SUMMARY AND CONCLUSIONS}

Costs associated with caring for 85 spinal patients injured in industrial accidents are presented in this paper and compared to data presented in a number of other published studies. We found mean first year hospitalisation costs for all patients to be $\$ 35,676$. For quadriplegics this amounted to $\$ 42,240$ and for paraplegics the mean figure was $\$ 32,6$ I9. During initial hospitalisation the average length of stay for all patients was I84 days at a mean cost of $\$ 28,637$. Room and 
board accounted for 52 per cent of costs, special services for 36 per cent, and professional services I I per cent. Major special service costs were private duty nursing, medications, medical supplies, respiratory and physical therapy. Various surgical specialties and physical medicine accounted for the major professional charges. Home care costs averaged $\$ 4000$ or $\$ 37$ per day.

In comparative terms the costs presented in our study are above those reported in other research. However, when median rather than mean costs are presented, the differential is markedly reduced as extreme values are somewhat neutralised (see Table I). It is most important to remember that not only are the cost figures in out study collected from all over the United States but also largely represent hospitalisation in general hospitals and not specialised spinal injury centres. Moreover, the patients are covered by one type of health insurance, Workmen's Compensation Insurance, which will change the aetiology of injury (fewer road accidents, more falls and hit by moving objects), and the age of the population (no one under I6 or over 65), hence possibly affecting injury severity, and mode of treatment vis-à-vis other general populations at risk.

It should be noted that in purest terms using hospitalisation as a cost measurement is not particularly good. Attitudes toward therapy and consequent lengths of stay (these two are extant costs) differ markedly among institutions. Moreover, some geographical areas have a plethora of empty rehabilitation or nursing home beds awaiting the needy patients while other areas have a long waiting list, so a patient remains in the acute care facility. Unfortunately we are pretty well stuck with this measure until a tool is developed that is sensitive enough to discriminate among such differences. Considering these differences, and that most published work to date has had to rely on retrospective, descriptive studies, it is interesting that the differences reported are not more marked. What will be exciting is the publication of the results of prospective cost studies on spinal cord injury presently in progress at Yale and elsewhere in the United States. Regardless of the findings, we would speculate that the data presented will once again confirm that from a cost standpoint, not to mention physical and psychological effects, spinal cord injury is devastating to patients and society.

\section{RÉSUMÉ}

Ces études rétrospectives et descriptives présentent les frais réels d'hospitalisation, au cours de la première année, pour une série de 85 malades souffrant de lésions de la moelle épinière. Ces malades étaient pourvus d'assurance contre les accidents du travail; et ils furent soignés dans de différentes institutions, aux Etats-Unis. Pendant cette première année à l'hôpital, les frais moyens, pour tous les malades, étaient de $\$ 35,676$ : soit, $\$ 42,240$ pour ceux atteints de quadriplégie; et $\$ 32,6$ I 9 pour les paraplégiques. Pendant l'hospitalisation initiale, seulement, la durée moyenne du séjour était de 184 jours, et le coût moyen de $\$ 28,637$. Pension et chambre représentaient 52 pour cent des frais; les services spéciaux, 36 pour cent; et les services professionels, I I pour cent. Les services spéciaux les plus importants, à cet égard, comprenaient les soins d'infirmières personnelles, les médications, les produits pharmaceutiques, et les traitements rsspiratoires et physiothérapiques. Les dépenses principales professionnelles se rapportaient aux specialités chirurgiques et physiothérapiques. Les dépenses moyennes des malades soignés chez eux étaient de $\$ 4000$ par personne, ou de $\$ 37.00$ par jour.

$\mathrm{Si}$ on compare notre étude aux autres, les frais détaillés ici se montrent plus élevés; cependant, cette différence est diminuée d'une façon prononcée si on considère le coût médian plutôt que le coût moyen. Mais lorsque l'on compare la seule autre enquête qui soit basée sur les frais réels, et non pas sur les frais estimatifs, les résultats se révèlent comme très semblables. Nous discutons les différences entre d'autres études et la nôtre, ainsi que les facteurs qui pourraient les expliquer. 


\section{ZUSAMMENFASSUNG}

Diese rückwirkende Studie beschreibt die tatsächlichen Krankenhauskosten während des ersten Jahres von 85 Patienten mit Rückgradsverletzungen, die durch die ArbeiterKompensations-Versicherung gedeckt sind, und deren Behandlung in verschiedenen Institutionen der Vereinigten Staaten stattfand. Die Durchschnitts-Hospitalkosten des ersten Jahres beliefen sich für alle Patienten auf $\$ 35,676$ - für Patienten mit Paralyse in vier Extremitäten auf $\$ \mathbf{4 2 , 2 4 0}$ und für Patienten mit Paralyse in zwei Extremitäten auf \$32,619. Während des anfänglichen Krankenhaus-Aufenthalts allein, verlief sich die Dauer auf I84 Tage und die Durchschnittskosten betrugen \$28,637. Zimmer und Verpflegungskosten betrugen $52 \%$, Spezialpflege $36 \%$ und Behandlung von Spezialisten I I \%. Spezialpflege konzentrierte sich hauptsächlich auf Privat-Schwestern, Medikamente, Verbandsmaterial, Atmungs- und physikalische Pflege. Bei Spezialistengebühren handelte es sich hauptsächlich um chirurgische Kosten und medizinisch-physikalischer Spezialbehandlung. Hauspflegekosten beliefen sich im Durchschnitt auf $\$ 4000$ pro Patient pro Tag.

Wenn man die Ergebnisse dieser Studie mit anderen vergleicht, so sind die hier berichteten Kosten höher, obwohl das Differential wesentlich verringert ist, wenn die allgemeinen anstatt Durchschnittskosten beschrieben werden. Wenn man diese wissenschaftliche Arbeit mit der einzigen anderen Publikation vergleicht-basiert auf tatsächlichen und nicht geschätzten Kosten-so sind die Resultate im Westenlichen die gleichen. Kosten-Unterschiede zwischen dieser und anderen Investigationen und die Gründe dafür wurden auch diskuriert.

Acknowledgements. This study was supported by the National Institute of Neurological and Communicative Disorders and Stroke (NS No. IOI74).

In addition, the project was made possible only through the full cooperation given by the Aetna Life and Casualty Insurance Company and The Travelers Insurance Companies, Hartford, Connecticut. We are especially grateful to Mr Alfred L. Green; William Guillette, M.D.; and Michael Mittelman, M.D., of the Aetna Life and Casualty Insurance Company as well as A. A. Dun, M.D.; Mr George Hatch; and Mr Peter C. Overbaugh at The Travelers Insurance Companies for their advice, spirit of cooperation and assistance throughout the project. Finally, our sincere thanks to Mr Edward O'Neill of the Yale Computer Center.

\section{REFERENCES}

BARrie, D. (1973). Non-medical management of spinal cord injury. Paraplegia, I2, 96.

Charles, E. D., Van Matre, J. G. \& Miller, J. M. (I974). Spinal cord injury-a cost benefit analysis of alternative treatment modals. Paraplegia, 12, 222.

Smart, C. N. \& SANDERs, C. R. (1976). The Costs of Motor Vehicle Related Spinal Cord Injuries. Insurance Institute for Highway Safety, Washington, D.C., U.S.A.

Thомas, P. J. (1974), Seven cost-effective models of treating spinal cord injuries. The Social and Rehabilitation Record, I, $\mathbf{7}$. 